\title{
Microflora associated with the alfalfa leafcutting bee, Megachile rotundata (Fab) (Hymenoptera: Megachilidae) in Saskatchewan, Canada
}

\author{
DW Goerzen \\ Saskatchewan Alfalfa Seed Producers Association 107 Science Crescent, \\ Saskatoon, SK, Canada S7N OX2
}

(Received 10 December 1990; accepted 1 August 1991)

\begin{abstract}
Summary - The microflora associated with Megachile rotundata was isolated from adult bees, larval cadavers, cell provisions, bee cell surfaces, and nest material. Dominant fungi included Alternaria alternata, Aspergillus niger, Eurotium chevalieri, Mucor sp, Penicillium spp, Saccharomyces sp, Trichoderma citrinoviride, and Trichosporonoides sp. Bacteria commonly isolated included Bacillus circulans, Bacillus mycoides, Enterobacter agglomerans, and Pseudomonas spp. These microorganisms may be involved in activities such as spoilage of provisions, production of enzymes, antibiotics, mycotoxins, and growth factors (vitamins, amino acids), metabolic conversion of provisions, and inhibition of competing microorganisms. Microbial succession was observed involving yeast and bacterial fermentation of provisions followed by mould overgrowth of cell contents; this process was often associated with larval mortality. The microflora isolated likely has a range of beneficial and deleterious effects on $M$ rotundata. Some fungal species reported here may also be potentially harmful to the health of leafcutting bee managers.
\end{abstract}

Megachlle rotundata / associated microfiora / fungus / bacterla / Canada

\section{INTRODUCTION}

The alfalfa leafcutting bee, Megachile rotundata ( $\mathrm{Fab}$ ), is an important domesticated pollinator of alfalfa and is widely utilized for alfalfa seed production in western Canada (Richards, 1987). Concerns related to the presence of chalkbrood (Ascosphaera aggregata Skou) in $M$ rotundata populations in the northwestern United States and southern Alberta have led to extensive surveying of Saskatchewan populations. While $A$ aggregata has been detected only sporadically and at very low levels in this province over the past 5 years (Goerzen, 1990), numerous other microorganisms have been isolated from various components of these populations. In this paper, the dominant microflora associated with $M$ rotundata is reported and the impact of these fungi and bacteria on $M$ rotundata populations is discussed.

\section{MATERIALS AND METHODS}

Isolates of microorganisms associated with $M$ rotundata populations were obtained by sampling adult bees, larval cadavers, spoiled cell provisions (ie stored pollen and nectar), bee 
cell surfaces, and tunnel surfaces in wood and polystyrene bee nest material.

In order to detect microflora on adult bees, female $M$ rotundata adults were captured in the field as they entered or exited nest tunnels and were placed in 1 dram glass vials containing $1 \mathrm{ml}$ sterile distilled water. Individuals were released following $30 \mathrm{~s}$ hand-agitation and samples were transferred to the laboratory for culture. As well, male and female $M$ rotundata adults newly emerged from cells incubated in the laboratory were individually placed in test tubes containing $1 \mathrm{ml}$ sterile distilled water, agitated in a vortex mixer for $30 \mathrm{~s}$, and the insects removed prior to sample culture. To evaluate microflora on the foliar exterior of leafcutting bee cells, groups of 150 cells from various populations were placed in 30-dram crystallite vials and washed with $25 \mathrm{ml}$ sterile distilled water. Tunnels in leafcutting bee nest material were sampled with sterile cotton-tipped wood applicators wetted with sterile distilled water. Applicators were stored in sterile glass culture tubes for transfer to the laboratory and rehydrated with 2 $\mathrm{ml}$ sterile distilled water prior to culture of samples.

All samples collected from adult bees, cell surfaces, and nest tunnels were plated in the laboratory as $0.1 \mathrm{ml}$ aliquots on potato dextrose agar (PDA), nutrient agar $\left(\right.$ Difco $\left.^{\circledR}\right)$, or Sabouraud's dextrose agar, incubated at $28{ }^{\circ} \mathrm{C}$, and assessed at 24-h intervals.

Cells containing larval cadavers and spoiled cell provisions were identified from samples of leafcutting bee cells examined in annual surveys of $M$ rotundata populations and from material collected in trapnests. Microflora associated with these specimens was plated directly on media via sterile loop transfer and incubated under the conditions described above.

Purified isolates from all sources were subcultured on PDA slants and stored at $4{ }^{\circ} \mathrm{C}$. Isolates were examined using lactophenol cotton blue mounts for preliminary identification; bacterial isolates were Gram-stained. Fungal isolates were submitted to the Biosystematics Research Centre, Ottawa, for identification; selected larval cadaver and cell provision specimens were also submitted. Bacterial isolates were submitted to the Agriculture Canada Research Station, Lethbridge, for identification. Voucher cultures of most isolates reported here have been deposited at DAOM, Ottawa.

\section{RESULTS}

The presence and relative abundance of microflora isolated from $M$ rotundata adults, larval cadavers, spoiled cell provisions, cell surfaces, and nest material are given in table I. Prevalent microorganisms associated with field-collected $M$ rotundata females included Alternaria alternata, Aspergillus niger, Enterobacter agglomerans, Penicillium spp, Pseudomonas solanacearum, Rhizopus arrhizus, and Trichosporonoides sp. Likely sources of these microorganisms were alfalfa plant surfaces and the leaves of other plants, including Chenopodium, Fagopyrum, Melilotus, and Rosa spp, which are commonly utilized for cell construction (Richards, 1984). The relative abundance of fungal and bacterial species fluctuated with temperature and moisture changes during the field season. Male and female $M$ rotundata emerging from laboratory-incubated cells were found to be carrying primarily $A$ alternata, Aspergillus niger, Enterobacter agglomerans, Eurotium chevalieri, and Trichosporonoides sp. All of these species were isolated frequently from the leaf surfaces of cells and likely picked up by individuals through contact during emergence.

Fungi commonly associated with larval cadavers included $\boldsymbol{A}$ niger, $\boldsymbol{E}$ chevalieri, Penicillium purpurogenum, $P$ simplicissimum, other Penicillium spp, and Trichosporonoides $\mathrm{sp}$, while dominant microorganisms found in conjunction with spoiled cell provisions included Ascosphaera pollenicola, A variegata, Aspergillus glaucus, A niger, Bacillus circulans, Enterobacter agglomerans, Eurotium chevalieri, Penicillium spp, Pseudomonas spp, and Trichosporonoides sp. Surfaces of $M$ rotundata cells were inhabited by a microfloral complex similar to that found in leafcutting bee nest material, with predominance of Alternaria alternata, Aspergillus niger, Enterobacter 
Table I. Microflora isolated from Megachile rotundata populations in Saskatchewan a.

\begin{tabular}{lllll}
\hline Microorganism & Adult \\
bee & Ladval & Cell & Cell Nest & Nest \\
provision surface material
\end{tabular}

Fungi

Alternaria alternata (Fr: Fr) Keissler

Ascosphaera aggregata Skou

Ascosphaera atra Skou and Hackett

Ascosphaera larvis Bissett

Ascosphaera pollenicola Bissett

Ascosphaera variegata Bissett

Ascosphaera sp

Aspergillus glaucus Link: Fr

Aspergillus niger Van Tiegham

Cylindrocarpon sp

Eurotium chevalieri L Mangin

Eurotium sp

Mucorsp

Penicillium purpurogenum O Stoll

Penicillium simplicissimum (Oudem) Thom

Penicillium spinulosum Thom

Penicillium spp

Rhizopus arrhizus A Fischer

Rhizopus sp

Saccharomyces sp

Trichoderma citrinoviride Bissett

Trichosporonoides $\mathrm{sp}$

Trichothecium roseum (Pers: Fr) Link

Ulocladium atrum $\mathrm{G}$ Preuss

Yeast-like sp NM-K (DAOM 212-057)

Yeast-like sp CE-I (DAOM 212-058)

Unidentified yeast-like sp Y01

Unidentified yeast-like sp Y02

\begin{tabular}{|c|c|c|c|c|}
\hline++ & + & & ++ & ++ \\
\hline & & + & & \\
\hline & + & + & & \\
\hline & & ++ & & \\
\hline & + & ++ & & \\
\hline & & & + & \\
\hline & + & ++ & & \\
\hline++ & ++ & ++ & +++ & +++ \\
\hline & & & + & + \\
\hline & ++ & ++ & +++ & +++ \\
\hline & & & + & + \\
\hline & & & ++ & ++ \\
\hline++ & & & & \\
\hline++ & & & & \\
\hline & & & & ++ \\
\hline++ & ++ & ++ & ++ & ++ \\
\hline++ & & + & +++ & +++ \\
\hline & & + & + & + \\
\hline & & ++ & & ++ \\
\hline & & & & ++ \\
\hline+++ & +++ & +++ & +++ & +++ \\
\hline+ & & & + & \\
\hline & & + & & + \\
\hline & & & + & + \\
\hline+ & & & + & \\
\hline+ & & & + & \\
\hline
\end{tabular}

Bacteria

Bacillus circulans Jordan

Bacillus mycoides Flugge

Bacillus sp

Corynebacterium sp

Enterobacter agglomerans Ewing and Fife

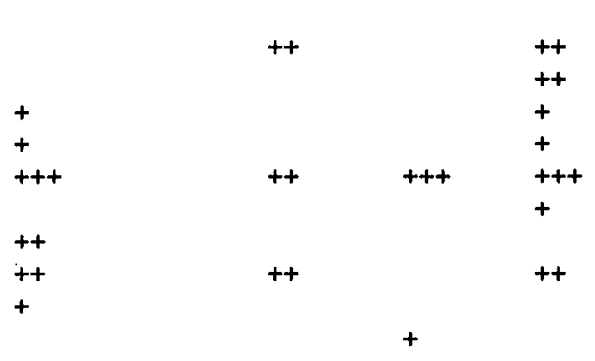

Flavobacterium breve (Lustig) Bergey

Pseudomonas solanacearum (Smith) Smith

Pseudomonas spp

Unidentified sp B01

Unidentified sp B02

a Isolation of microorganisms from $M$ rotundata populations is rated as occasional $(+)$, frequent $(++)$, or abundant $(+++)$. 
agglomerans, Eurotium chevalieri, Mucor $\mathrm{sp}$, Penicillium spp, Rhizopus spp, and Trichosporonoides sp. Other species commonly isolated from nest material were $\mathrm{Ba}$ cillus circulans, B mycoides, Corynebacterium sp, Pseudomonas spp, and Trichoderma citrinoviride. The yeast Saccharomyces $\mathrm{sp}$ was frequently found in cultures from wood nest material but rarely isolated from polystyrene nest material.

\section{DISCUSSION}

The dominant species of filamentous fungi listed (ie A alternata, Aspergillus niger, $E$ chevalieri, Mucor sp, Penicillium spp, $R$ arrhizus, and $T$ citrinoviride) are generally saprophytic in nature, growing on available material including cell provisions, larval cadavers, and the foliar surface of cells. However, other fungal species reported here, including Aspergillus spp and Trichothecium roseum, can be pathogenic on wild bees (Batra et al, 1973). While $A$ aggregata, the causative agent of chalkbrood in $M$ rotundata, is rarely detected in Saskatchewan leafcutting bee populations, several other Ascosphaera spp have been isolated and 2 of them, $A$ pollenicola and $A$ variegata, are frequently found in spoiled cell provisions, usually in conjunction with $E$ chevalieri and Trichosporonoides sp. The species $\boldsymbol{A}$ atra and $\boldsymbol{A}$ pollenicola appear to be primarily saprophytic on cell provisions, while $A$ larvis and $A$ variegata are usually isolated from $M$ rotundata larval cadavers and may be pathogenic to the leafcutting bee (Bissett, 1988).

Extensive research in the identification of fungal species associated with the honeybee (Apis mellifera) indicated that the most commonly occurring moulds were Aspergilli, Mucorales, and Penicillia (Gilliam and Prest, 1987; Gilliam et al, 1989a, 1989b). Richards (1985), in surveys to detect Ascosphaera aggregata in $M$ rotunda- ta populations, noted the occurrence of Fusarium, Mucor, Penicillium, and Rhizopus spp. Except for the absence of Fusarium $\mathrm{sp}$, the dominant mould species reported for $M$ rotundata in this study are similar, with Alternaria and Eurotium spp also commonly isolated. As noted by Gilliam et al (1989a), moulds merit intensive study due to their activity in the production of enzymes and numerous secondary metabolites including antibiotics, terpenes, and polysaccharides. Research currently underway to investigate possible antagonistic interactions between $A$ aggregata and other microflora associated with $M$ rotundata (Goettel, Agriculture Canada, Lethbridge, personal communication) is important for the insight it will provide into the complex relationships existing among these microorganisms. Seven of the 22 fungal species reported here are known to produce mycotoxins. These include Aspergillus niger (malformin C), $E$ chevalieri (gliotoxin), $P$ purpurogenum (rubratoxin), $P$ simplicissimum (penicillic acid), $P$ spinulosum (spinulosin), $T$ citrinoviride (T-2 toxin), and $T$ roseum (trichothecin) (Wyllie and Morehouse, 1977; Moreau, 1979).

Members of the genus Trichosporonoides, which were isolated in abundance from every component of the leafcutting bee system examined here, are yeast-like fungi which are not well known and are in need of taxonomic revision. The strains of Trichosporonoides isolated were somewhat variable in cultural characteristics and morphology, and may represent a single species complex which has yet to be described (Bissett, personal communication). The unique morphology and development of this genus was first described by $\mathrm{Ha}$ skins and Spencer (1967), who isolated Trichosporonoides oedocephalis Haskins and Spencer from brood cell material in Apis mellifera honeycomb.

Saccharomyces $s p$ was frequently isolated from wood nest material and spoiled 
cell provisions, but was never present in abundance. An additional 2 as yet unidentified yeast-like species are currently under evaluation at the Biosystematics Research Centre, Ottawa (DAOM 212-057, DAOM 212-058). These species, along with unidentified yeast-like species designated Y01 and Y02, were isolated occasionally from field-captured adult bees, cell surfaces, or nest material. In work describing yeasts in pollen and bee bread, Gilliam (1979a) isolated 113 yeasts in 7 genera which were associated with almond (Prunus dulcis) pollen either from the flower or stored in comb cells of $A$ mellifera hives. This demonstrates the diversity of yeast flora which may be associated with bee populations. As noted by Gilliam (1979a), the role of yeasts in processes relating to bee nutrition is as yet poorly defined, but may involve production of necessary growth factors including vitamins and amino acids.

Bacteria dominant in this study included Bacillus circulans, $B$ mycoides, Enterobacter agglomerans, and Pseudomonas spp. These were isolated most often from adult bees, cell provisions, and nest material. Enterobacter agglomerans was also abundant on cell surfaces. Two unidentified bacterial species, designated $\mathrm{B} 01$ and $\mathrm{B} 02$, were isolated infrequently from adult bees and cell surfaces. In reports of bacteria associated with $A$ mellifera (Gilliam, $1979 \mathrm{~b})$, the stingless bee, Melipona fasciata (Gilliam et al, 1990a), and 5 species of solitary bees (Gilliam et al, 1984, 1990b), Bacillus spp were dominant, and in all cases, $B$ circulans was isolated. Gilliam et al (1990b) concluded that Bacillus spp are common associates of Apoidea and could participate in metabolic conversion of provisions and in inhibition of competing and spoilage microorganisms.

The presence of this diverse group of fungi and bacteria associated with $M$ ro- tundata populations in Saskatchewan probably has a broad range of effects on these populations. As noted, the microorganisms may contribute to the production of many beneficial compounds such as antibiotics, vitamins, amino acids, and antispoilage agents. However, many of the species listed may also harm leafcutting bee populations by interfering with larval development and spoiling cell provisions. In laboratory studies, $B$ circulans and Pseudomonas spp, in conjunction with Saccharomyces and Trichosporonoides spp, were observed to cause larval mortality through fermentation of cell provisions. The spoilage of cell provisions often led to subsequent overgrowth of cell contents by Aspergillus niger, Penicillium spp, and $R$ arrhizus (Goerzen, unpublished data). This process of microbial succession in cells was reported previously in the alkali bee, Nomia melanderi (Batra et al, 1973). In addition to exhibiting antibacterial and fungistatic activity, toxins associated with some fungal species isolated here have been shown to elicit responses including feeding aversion and inhibition of protein synthesis (Moreau, 1979). Any of these processes could contribute to leafcutting bee larval mortality found in populations evaluated in this study. Surveys of Saskatchewan leafcutting bee populations undertaken over the 5-year period 1985 to 1989 have shown the percentage of cells containing dead larvae, mouldy larvae, and spoiled provisions to range from $6.9-11.9 \%$ of total cells evaluated (Goerzen, 1990).

Many of the mould species found in association with the alfalfa leafcutting bee may be potentially harmful to the health of leafcutting bee managers as well. Alternaria, Aspergillus, Penicillium and Rhizopus spp are among those fungi which are considered most important medically (Aukrust et al, 1985). These species have been implicated in allergic reactions and broncho- 
pulmonary disease and may cause conditions ranging from pulmonary hypersensitivity disease (eg allergy, asthma) to lifethreatening infection (Pennington, 1986). During leafcutting bee incubation and cellharvesting operations, large numbers of emerging bees or loose cells concentrated in confined areas may lead to high levels of airborne spores of these species. Several less frequently isolated mould species reported here, including Cylindrocarpon, Trichoderma, and Ulocladium spp, are not ordinarily associated with human diseases but under certain conditions may act as opportunistic pathogens (Rippon, 1987).

Identification of the microflora associated with $M$ rotundata is important in elucidation of the complex interactions between this economically important solitary bee species and the microorganisms present in its environment. A reduction in high levels of mould species which may interfere with larval development and spoil cell provisions will assist in increasing the quality of alfalfa leafcutting bee populations. An awareness of the presence of mould species which have been implicated in human allergic reactions will allow leafcutting bee managers to take measures to reduce contact with potentially harmful spores and to incorporate control techniques which will reduce levels of non-beneficial microorganisms in $M$ rotundata populations. However, the beneficial effects associated with the presence of a balanced complement of microorganisms in the leafcutting bee ecosystem are doubtless of great importance and require further study.

\section{ACKNOWLEDGMENTS}

I thank $M$ Erlandson and $D$ Murrell for continuing assistance and encouragement, $M$ Goettel and $\mathrm{K}$ Moore for critical review of the manuscript, J Bissett for determination of fungal species, and R Phillipe for determination of bacteri- al species. This research was supported by the Canada-Saskatchewan Economic Regional Development Agreement and the Saskatchewan Agriculture Development Fund.

Résumé - Étude de la microflore associée à la mégachile Megachile rotundata (Fab) (Hymenoptera: Megachilidae) au Saskatchevan, Canada. Des isolats de champignons et de bactéries, associés à des populations de Megachile rotundata, ont été obtenus par échantillonnage d'abeilles adultes, de cadavres de larves, de provisions endommagées contenues dans des cellules, de la surface de cellules de couvain, et de la surface des tunnels présents dans le nid. Les abeilles adultes et les surfaces des cellules ont été traitées par lavage dans de l'eau distillée stérile, alors que les prélèvements des tunnels ont été réalisés avec des tiges de bois munies de coton à leur extrémité. Au laboratoire, les échantillons ont été recouverts avec de l'agar dextrose de pomme de terre, de l'agar nutritif, et de l'agar dextrose de Sabouraud, et incubés à $28^{\circ} \mathrm{C}$. La microflore associée aux cadavres de larves et aux provisions endommagées a été transférée dans les milieux au moyen d'un instrument stérile. Les isolats purifiés de champignons ont été examinés en utilisant du lactophénol, et les isolats de bactéries ont été colorés par la coloration de Gram.

La présence et l'abondance de la microflore isolée de populations de $M$ rotundata sont données dans le tableau I. Les microorganismes dominants sont : les champignons Alternaria alternata, Aspergillus niger, Eurotium chevalieri, Mucor sp, Penicillium spp, Rhizopus arrhizus, Saccharomyces sp, Trichoderma citrinoviride, and Trichosporonoides sp; les bactéries $\mathrm{Ba}$ cillus circulans, B mycoides, Enterobacter agglomerans, and Pseudomonas spp. Un grand nombre des espèces de champignons présents sont saprophytes, et crois- 
sent sur les provisions et les cadavres de larves. Cependant, Aspergillus spp et Trichothecium roseum sont connus pour être pathogènes pour les abeilles sauvages.

Les champignons peuvent également jouer un rôle important pour leur activité dans la production d'enzymes, d'antibiotiques et de mycotoxines. Le champignon, voisin des levures, Trichosporonoides a été isolé dans tous les types d'échantillons analysés. Le rôle des levures dans la nutrition de l'abeille peut consister en la production de vitamines et d'acides aminés. Les bactéries dominantes dans cette étude peuvent participer à la transformation métabolique des provisions et à l'inhibition des microorganismes en compétition avec elles.

La microflore isolée des populations de mégachiles a vraisemblablement à la fois des effets bénéfiques et nuisibles. Tandis que beaucoup d'espèces de champignons et de bactéries peuvent contribuer à la production de composés utiles, d'autres peuvent interférer avec le développement larvaire et abimer les provisions. Cette microflore est souvent associée à des mortalités larvaires. Les moisissures, incluant $A$ /ternaria, Aspergillus, Penicillium et Rhizopus spp pourraient également être potentiellement nocives pour les éleveurs de ces abeilles. Pendant les opérations de récolte en particulier, un très grand nombre d'abeilles et de cellules, qui sont maintenues dans des zones confinées, peuvent émettre dans l'air ambiant, de grandes quantités de spores provenant de ces moisissures, qui ont été impliqués dans des réactions allergiques et des maladies bronchopulmonaires. L'identification de la microflore associée à $M$ rotundata est importante pour la compréhension des intéractions complexes existant entre cette importante espèce d'abeilles solitaires et les microorganismes présents dans l'environnement. Tandis qu'une réduction du ni- veau élevé d'espèces de moisissures nuisibles pour $M$ rotundata permettrait d'accroître la qualité des populations de cette abeille, les effets bénéfiques de quelques microorganismes pourraient être d'une grande importance, et nécessitent des études ultérieures.

Megachile rotundata / microflore associée / champignons / bactéries / Canada

Zusammenfassung - Die mit der Luzerne-Blattschneiderbiene (Megachile rotundata) in Saskatchewan, Kanada, assoziierte Mikroflora. Durch Probenentnahme von erwachsenen Bienen, toten Larven, verdorbenen Zellvorräten, der Oberfläche der Bienenzellen sowie des Materials der Neströhre wurden Isolate von Pilzen und Bakterien gewonnen, die zusammen mit den Populationen von $\mathrm{Me}$ gachile rotundata vorkommen. Die Proben von den Bienen und der Zelloberfläche wurden durch Waschen in destilliertem Wasser gewonnen, während die Proben von dem Material der Neströhren mittels eines sterilen Wattebausches entnommen wurden. Die Proben wurden im Laboratorium auf Kartoffel-Dextrose-Agar, Nähragar oder Sabouraud's Dextrose-Agar ausgestrichen und bei $28^{\circ} \mathrm{C}$ inkubiert. Die Mikroflora in toten Larven oder verdorbenen Zellvorräten wurden mittels einer sterilen Öse auf das Nährmedium übertragen. Gereinigte Pilzisolate wurden in mit Lactophenolblau gefärbten Präparaten untersucht, Bakterien-lsolate wurden gramgefärbt. Die Art und relative Häufigkeit der von $M$ rotundata-Populationen isolierten Mikroflora ist aus Tabelle I ersichtlich. Unter den vorherrschenden Mikroorganismen befanden sich die Pilze Alternaria alternata, Aspergillus niger, Eurotium chevalieri, Mucor sp, Penicillium spp, Rhizopus arrhizus, Saccharomyces $\mathrm{sp}$, Trichoderma citrinoviride und Trichosporonoides sp; an Bakterien 
wurden Bacillus circulans, B mycoides, Enterobacter agglomerans und Pseudomonas spp gefunden. Viele von den Pilzarten sind Saprophyten, die auf derartigen Materialen wie Zellvorräten und toten Larven wachsen. Von Aspergillus spp und Trichothecium roseum ist jedoch bekannt, daß sie für Wildbienen pathogen sind. Pilze können auch für die Produktion von Enzymen, Antibiotika und Mykotoxinen wichtig sein. Der Hefe-ähnliche Pilz Trichosporonoides wurde von allen komponenten des Blattschneiderbienen-Systems isoliert. Die Rolle von Hefen in Bezug auf die Ernährung der Bienen kann die Erzeugung von Vitaminen und Aminosäuren einschlieBen. Die in dieser Untersuchung vorherrschenden Bakterien können bei der Umwandlung der Zellvorräte im Stoffwechsel und bei der Hemmung von anderen Mikroorganismen von Bedeutung sein.

Die von den Populationen der LuzerneBlattschneiderbiene isolierte Mikroflora besitzt wahrscheinlich Effekte, die von nützlich bis schädlich reichen. Während viele Pilz- und Bakterienarten zu der Erzeugung nützlicher Verbindungen beitragen mögen, können andere die Larvenentwicklung stören und die Zellvorräte verderben. Die mikrobielle Entwicklung, wie sie im Laboratorium beobachtet wurde und welche die Hefe- und bakterielle Gärung der Vorräte und eine Schimmelüberwucherung des Zellinhalts betraf, war oft mit dem Absterben der Larven verbunden. Schimmelpilze, einschließlich Alternaria-, Aspergillus-, Penicillium- und Rhizopus-Arten können potentiell auch für die Betreuer der Blattschneiderbienen schädlich sein. Während des Ausbrütens der Bienen und der Tätigkeiten der Ernte reifer Zellen, können große Mengen von Bienen oder Bienenzellen in geschlossenen Räumen zu einer hohen Sporenkonzentration dieser medizinisch wichtigen Schimmelpilze in der Luft führen und in der Folge zu allergischen
Reaktionen und bronchopulmonalen Erkrankungen.

Die Bestimmung der mit $M$ rotundata assoziierten Mikroflora ist für die Aufklärung der komplexen Wechselwirkungen zwischen dieser wirtschaftlich wichtigen solitären Bienenart und den in ihrer Umwelt vorhandenen Mikroorganismen wichtig. Während die Reduktion einer Überzahl für $M$ rotundata schädlicher Schimmelpilze die Qualität der Populationen von Blattschneiderbienen verbessern wird, kann der günstige Einfluß einiger Mikroorganismen von so großer Bedeutung sein, daß weitere Untersuchungen gerechtfertigt werden.

Megachile rotundata / assoziierte Mikroflora / Pilz / Bakterien / Kanada

\section{REFERENCES}

Aukrust L, Borch SM, Einarsson R (1985) Mold allergy - spores and mycelium as allergen sources. Allergy 40 (suppl 3), 43-48

Batra LR, Batra SW, Bohart GE (1973) The mycoflora of domesticated and wild bees (Apoidea). Mycopathol Mycol Appl 49, 13-44

Bissett $J$ (1988) Contribution towards a monograph of the genus Ascosphaera. Can J Bot $66,2541-2560$

Gilliam M (1979a) Microbiology of pollen and bee bread: the yeasts. Apidologie 10, 43-53

Gilliam M (1979b) Microbiology of pollen and bee bread: the genus Bacillus. Apidologie 10, 269-274

Gilliam M, Prest DB (1987) Microbiology of feces of the larval honey bee, Apis mellifera. $J$ Invertebr Pathol 49, 70-75

Gilliam M, Buchmann SL, Lorenz BJ (1984) Microbial flora of the larval provisions of the solitary bees, Centris pallida and Anthophora sp. Apidologie 15, 1-10

Gilliam M, Prest DB, Lorenz BJ (1989a) Microbiology of pollen and bee bread: taxonomy and enzymology of molds. Apidologie 20, 5368 
Gilliam M, Prest DB, Lorenz BJ (1989b) Microbes from apiarian sources: molds in grass from larvae of the greater wax moth, Galleria mellonella. J Invertebr Pathol 54, 406-408

Gilliam M, Roubik DW, Lorenz BJ (1990a) Microorganisms associated with pollen, honey, and brood provisions in the nest of a stingless bee, Melipona fasciata. Apidologie 21, 89-97

Gilliam M, Buchmann SL, Lorenz BJ, Schmalzel RJ (1990b) Bacteria belonging of the genus Bacillus associated with three species of solitary bees. Apidologie 21, 99-105

Goerzen DW (1990) Leafcutter bee foliar moulds, their effects on bee populations and producer health, and methods for their control. In: Proc 21st Ann NW Alfalfa Seed Conf Pasco WA, 21-26

Haskins RH, Spencer JFT (1967) Trichosporonoides oedocephalis n gen, $\mathrm{n}$ sp. I. Morphology, development, and taxonomic position. Can J Bot 45, 515-520
Moreau C (1979) Moulds, Toxins, and Food. John Wiley and Sons, NY

Pennington JE (1986) Aspergillus. In: Fungal Diseases of the Lung (Sarosi GA, Davies SF, eds) Grune and Stratton Inc, NY, 175-189

Richards KW (1984) Alfalfa leafcutter bee management in western Canada. Agric Can Publ 1495/E, 1-53

Richards KW (1985) Detection of a chalkbrood fungus, Ascosphaera aggregata, in larvae of the alfalfa leafcutter bee (Hymenoptera: Megachilidae) from western Canada. Can Entomol 117, 1143-1145

Richards KW (1987) Alfalfa leafcutter bee management in Canada. Bee World 68, 168-178

Rippon JW (1987) The new opportunistic fungal infection: diagnosis, isolation, identification, and impact on mycology. Mycopathologia 99, 143-146

Wyllie TD, Morehouse LG (1977) Mycotoxic Fungi and Chemistry of Mycotoxins. Marcel Dekker Inc, NY 